\title{
The Effect of PUJB Subjects (Food Service Business Management) and Industrial Work Practice on Entrepreneurship Competence of Vocational School Students in Catering Service Expertise
}

\author{
Kezia Eka Purwaningtyas* Luthfiyah Nurlaela, Euis Ismayati, Tri Rijanto, \& Marniati \\ Postgraduate of State University of Surabaya, Surabaya, 60213, Indonesia. \\ kezia.19005@mhs.unesa.ac.id \\ *Corresponding Author: marniati@unesa.ac.id; luthfiyahnurlaela@unesa.ac.id | Phone Number: +6285335660554
}

\begin{abstract}
This article aims to find out how food service business management subjects and industrial work practices affect the entrepreneurial competence of Vocational Education and Training (VET) students. The quantitative approach is to process the data and the numbers are obtained through statistical analysis. The data source used in this study is primary data or data obtained directly from respondents. This study aims to examine the effect of the independent variable (free), namely PUJB (X1), industrial work practice (X2) subjects on the dependent variable (dependent), namely entrepreneurial competence $(\mathrm{Y})$. Researchers took a sample of 81 respondents. Data collection by giving questionnaires to respondents to all students majoring in marketing class XII at SMKN 2 Mojokerto. Based on the data from the results of research and tests that have been carried out, the conclusions are: (1) PUJB subjects affect the entrepreneurial competence of class XII students of the Catering Services study program at SMKN 2 Mojokerto. (2) Internship has an effect on the entrepreneurial competence of class XII students of the Catering Service study program at SMKN 2 Mojokerto. (3) PUJB and apprenticeship subjects affect the entrepreneurial competence of class XII students of the Catering Service study program at SMKN 2 Mojokerto.
\end{abstract}

Keywords: PUJB subject; industrial work practice; entrepreneurship; competence of vocaional school

\section{Introduction}

Entrepreneurship is an alternative in overcoming unemployment. Entrepreneurs who are able to create their own jobs will provide job vacancies for other people, thereby reducing unemployment and improving the economy of a country. The percentage of the number of entrepreneurs is also a benchmark for the status of a country because if you have entrepreneurs of more than $14 \%$ of the population ratio, the country is a developed country. However, according to BPS data, until 2019 Indonesia only had 3.1\% of business actors from the total population ratio (BPS, 2019). Entrepreneurship is a complex activity in which many factors must be possessed by graduates who wish to open a business. In addition to the interest factor, someone who will carry out entrepreneurial activities must have entrepreneurial competence. Entrepreneurial competence is needed so that someone can survive the competition that is sure to occur in the entrepreneurial world. Tittle and Terzidis (2020) divide the entrepreneurial competence domain possessed by SMK graduates into three levels including personal level, social level, and professional level. European Council (2018) provides a definition of personal competence, namely "Ability to reflect upon oneself, manage time \& information, learning \& career". Self-competence is the ability to reflect on yourself, manage time and information, study and career. Social level or relevance competence includes the ability to communicate, solve problems, uphold high morale and a positive attitude in teamwork and external partners. Meanwhile, the professional level is a competency needed to identify opportunities, develop organizations and take advantage of opportunities.

Entrepreneurial competence is an important factor for someone who will open a business. This competence enables a person to be able to run a business well. Dollinger (2003) argues that entrepreneurial competence is a fundamental characteristic of an individual in creating creative and innovative opportunities or opportunities. The criteria for an entrepreneur are creative and innovative, the ability to gather resources, turn opportunities into profits under conditions of risk and uncertainty. Entrepreneurial competence can be formed through the environment, for example the school and industrial environment. A school environment that is able to form entrepreneurial competencies can be done by providing 
entrepreneurial knowledge and skills to students, for example through lessons in catering business management. An industrial environment that is able to provide entrepreneurial experiences to students is to do industrial work practices.

The subject of catering business management is the arrangement of an activity in the field of food and beverage in large quantities and is carried out commercially. In accordance with its commercial nature, the purpose of managing a catering business is to make a profit in accordance with economic principles (Endah Saraswati, M.M., et al, 2016: 7). The Java Boga Business Management (PUJB) is a subject that involves students directly learning entrepreneurship from an early age, because in this subject students are taught how to manage a business. Starting from the preparation stage of materials and equipment, processing techniques, packaging, marketing, and how to calculate the selling price so that the catering service business gets a profit in accordance with the main goal of entrepreneurship (Astika, 2019).

Industrial Work Practice (Prakerin) is the right solution to increase the relevance between SMK and DU /DI (Edi \& Widiastuti, 2017). The implementation of industrial practice will provide insights and knowledge to students about the real world of work. In addition, with industrial practice, students can apply the theories that have been obtained in Vocational High Schools (SMK) and can hone their skills. The implementation of industrial practice, students should be serious so that students are able to gain experience and knowledge that is useful and useful. Having a serious attitude when implementing industrial practices, students will be familiar with the real world of work and can improve the skills of students (Sahputra, 2016). Experience in internship is an experience that students experience directly through direct participation and observation in the world of work (Hamalik, 2008). This experience is a form of physiological experience that can influence individual development (Dalyono, 2005).

This article is a research article entitled the influence of the subject of Food Service Business Management and Internship on the entrepreneurial competence of students in SMK. The assessment was carried out by taking samples of grade 12 students in the Catering expertise program at SMK Negeri 2 Mojokerto. The purpose of this study was to determine the extent of the influence of the subject of Food Service Business Management and Internship on the entrepreneurial competence of students in SMK.

\section{Literature Review}

\subsection{PUJB (Food Service Business Management)}

The subject of catering business management is the arrangement of an activity in the field of food and beverage in large quantities and is carried out commercially. In accordance with its commercial nature, the purpose of managing a catering business is to make a profit in accordance with economic principles based on Endah Saraswati, M.M., et al, (2016). The Java Boga Business Management (PUJB) is a subject that involves students directly learning entrepreneurship from an early age, because in this subject students are taught how to manage a business. Starting from the preparation stage of materials and equipment, processing techniques, packaging, marketing, and how to calculate the selling price so that the catering service business gets a profit in accordance with the main goal of entrepreneurshi, according by Astika (2019).Catering business is an activity to seek profit by providing services to consumers in the food sector. Fadiati A. stated (2011: 16) "Food service business comes from the word cater which means preparing and serving food and drinks to the public. Judging from the type of business, a restaurant is one of them. "

Based on the curriculum structure SMK 2013 revision (2018) catering business management lessons will be studied in class XII semester 1 and semester 2. In subjects competency catering business management foundation to be studied in semester 1 among others: (1) analyzing the type of business catering and planning a catering business and determine the type of catering business can be developed based on consumer needs, (2) analyze food purchase procedures and make food purchases (3) implementing acceptance, storage groceries, do receipts and storage of foodstuffs, (4) implement purchasing administration, receipt and storage of materials food and make administration purchase, receipt and storage foodstuff, (5) evaluating production of food service business products and doing food business production.

\subsection{Industrial Work Practice}

Industrial Work Practice (Prakerin) is the right solution to increase the relevance between SMK and DU/ DI (Edi \& Widiastuti, 2017). The implementation of industrial practice will provide insights and knowledge to students about the real world of work. In addition, with industrial practice, students can apply the theories that have been obtained in Vocational High Schools (SMK) and can hone their skills. The implementation of industrial practice, students should be serious so that students are able to gain experience and knowledge

that is useful and useful. Having a serious attitude when implementing industrial practices, students will be familiar with the real world of work and can improve the skills of students (Sahputra, 2016). Experience in 
internship is an experience that students experience directly through direct participation and observation in the world of work (Hamalik, 2008). This experience is a form of physiological experience that can influence individual development (Dalyono, 2005).

Industrial Work Practices are beneficial for students to gain experience in the world of work and foster confidence in students. In addition, by participating in Industrial Work Practices, students can train and support the skills that have been learned in school to be implemented in the Industrial Workplace, can live and get to know the work environment so that students are ready to work in the business world and industry after graduating from Vocational School, according Usman (2019). Lestari (2019) said, industrial work practices are the implications of school education activities with industry work teams that involve students to work directly in the industrial work team.

\subsection{Entrepreneurship Competence}

Entrepreneurial competence is a fundamental characteristic of an individual in creating creative and innovative opportunities or opportunities. This is reinforced by Dollinger (2003: 5) that the criteria for an entrepreneur are creative and innovative, the ability to gather resources, turn opportunities into profits under conditions of risk and uncertainty. Tyas (2015) attaches the characteristics and traits that entrepreneurs must have according to Georey (1996), among others; confident and optimistic, oriented to tasks and results, dare to take risks and like challenges, leadership, originality and future-oriented. Zainal, et al. (2018) identified entrepreneurial competence as commitment, strategic, and organizational skills.

Inyang \& Enuo (2009) define entrepreneurial competence as a group of knowledge, attitudes, and related skills that a person must acquire after attending entrepreneurship training. These competencies consist of time management, marketing management, business ethics, leadership, decision making, and financial management. . Another perspective divides entrepreneurial competence into 2 more specific types of competencies, namely personal competence and functional competence. On the other hand, Mitchelmore \& Rowley (2010) divided entrepreneurial competencies into 4 groups into personality and relationships, business management, entrepreneurship, and human resource competencies.

Based on the opinions of several experts above, it can be concluded that entrepreneurial competence is an ability required by individuals in entrepreneurial activities. This research will refer to the domain of Tittle and Terzidis (2020) in three levels including personal level, social level, and professional level. Selfcompetence is the ability to reflect on yourself, manage time and information, study and career. Social level or relevance competence includes the ability to communicate, solve problems, uphold high morale and a positive attitude in teamwork and external partners. Meanwhile, the professional level is a competency needed to identify opportunities, develop organizations and take advantage of opportunities.

\section{Materials and Methods}

This research is a quantitative descriptive study in which the quantitative research method is a research method based on the philosophy of positivism, used to examine certain populations or samples with the aim of testing predetermined and generalizable hypotheses (Sugioyono, 2013). The quantitative approach is to process the data and the numbers are obtained through statistical analysis. The data source used in this study is primary data or data obtained directly from respondents. This study aims to examine the effect of the independent variable (free), namely PUJB (X1), industrial work practice (X2) subjects on the dependent variable (dependent), namely entrepreneurial competence $(\mathrm{Y})$.

Population is a generalization area consisting of objects that have certain qualities and characteristics that are determined by researchers to study and then draw conclusions (Sugioyono 2011: 80). This study used a population of all students of class XI SMK Catering Service study program in Mojokerto. The sample is part of the number and characteristics possessed by this population. The population in this study was class XII culinary services amounting to 81 people. The criteria in this study are (1) students of the catering services study program who have carried out industrial work practices and (2) students of the catering services study program who have taken PUJB/Catering subjects with a KKM value of 70 . all students have the criteria of respondents determined by the researcher. Saturated sampling is a sampling technique in which the entire population membership becomes the research sample (Sugiyono, 2015). Researchers took a sample of 81 respondents. Data collection by giving questionnaires to respondents to all students majoring in marketing class XII at SMKN 2 Mojokerto.

According to Sugiyono (2011) a questionnaire is a data collection technique that is done by giving a set of questions or written statements to respondents to answer. In this study, the questionnaire used was closed and the answers were available and the respondents only gave a sign to the available answers. The questionnaire used in this study was given to students as research respondents who were used to obtain 
data to determine the independent variable (free), namely the PUJB subject (X1), industrial work practice $p$ (X2) on the dependent variable (dependent), namely entrepreneurial competence (Y). The research instrument is a tool used to measure observed natural and social phenomena. The instrument in this study used a closed questionnaire whose answers were already available and the respondents only gave a sign to the alternative answers that were available. The questionnaire was arranged based on the lattice of the instrument from the variables used in this study, namely the PUJB subject (X1), industrial work practice (X2) on the dependent variable (dependent), namely entrepreneurial competence $(\mathrm{Y})$.

The analysis in this study uses multiple regression analysis which serves to determine whether there is influence between the independent variables on the dependent variable. In this case the independent variable in the PUJB subject (X1), internship (X2) on the dependent variable (bound), namely entrepreneurial competence $(\mathrm{Y})$. The $\mathrm{t}$ test is a test used to determine whether the independent variable in the regression model partially has a significant effect on the dependent variable. This test aims to test the regression coefficient hypothesis individually. The $t$ test concludes that if the prob value is $>0.05$, then $\mathrm{H} 0$ is accepted. $\mathrm{H} 1$ is rejected, meaning that there is no partial influence between the independent variable and the dependent variable. If the prob value $<0.05$, then $\mathrm{H} 0$ is rejected $\mathrm{H} 1$ is accepted, meaning that there is an influence between the independent variable and the dependent variable partially. The F test is used to test hypotheses involving more than one coefficient (Sarwoko, 2005: 72). This test shows whether all the independent variables included in the regression model have a joint influence on the dependent variable.

\section{Results and Discussions}

The results of this study were obtained from respondents at SMKN 2 Mojokerto. The researchers distributed 81 questionnaires to all students in class XII of the catering service study program. Giving a questionnaire to the respondent containing 23 points of statement. Then the results of the answers to the questionnaire were collected to the researcher for data analysis using the SPSS version 21.0 program.

It can be seen that the multiple regression equation include:

$$
Y=45,424+0,300 X 1+0,567 X 2+e
$$

Means :

X1 : PUJB subject

$\mathrm{X} 2$ : Industrial Work Practice

$\mathrm{Y}$ : entrepreneurial competence

The effect of PUJB Subjects on entrepreneurship Competence

Table 1. Results of Multiple Linier Regression Analysis (X1)

\begin{tabular}{ccccc}
\hline Model & Regression coefficient & T & T Table & Sig. \\
\hline PUJB subject & 0,148 & 1,522 & 0,949 & 0,005 \\
\hline
\end{tabular}

(source: data processed by researchers, 2020)

Based on table 1, it shows that PUJB subjects have a positive regression coefficient of 0.148 which means that there is a unidirectional influence between PUJB subjects (X1) and entrepreneurial competence (Y). This can also be interpreted that if the PUJB subject is implemented properly, it will increase the entrepreneurial competence of students. The $t$ test on the PUJB subject variable shows that the $t$ score is greater than the $t$ table $(1.522>0.949)$ and the significant value is $0.005<0.05$, which means significant. So that the first hypothesis "PUJB subjects affect entrepreneurial competence" can be accepted. Based on the questionnaire that has been answered, most of the respondents agree, with a statement stating that the PUJB subject can improve students' entrepreneurial competence. This means that the experience of industrial work practices has a positive influence on entrepreneurial readiness. PUJB learning in schools will produce graduate students who are ready to open a business. Therefore, the school really prepares debriefing so that the PUJB learning process is good and smooth, and has a good and positive impact on the students who carry it out.

The effect of Industrial Work Practice on entrepreneurship Competence

Table 2. Results of Multiple Linier Regression Analysis (X2)

\begin{tabular}{|c|c|c|c|c|}
\hline Model & Regression coefficient & $\mathrm{T}$ & T Table & Sig. \\
\hline Industrial Work Practice & 0,148 & 1,522 & 0,949 & 0,005 \\
\hline
\end{tabular}

(source: data processed by researchers, 2020)

Based on table 2, it shows that industrial work practice has a positive regression coefficient of 0.351 which means that there is a unidirectional influence between industrial work practice (X2) and entrepreneurial competence $(\mathrm{Y})$. It can also be interpreted that if industrial work practices are carried out 
properly, it will increase the entrepreneurial competence of students. The $t$ test on the industrial work practice variable shows that the $t$ value is greater than the $t$ table $(5.470>0.949)$ and the significant value is $0.000<0.05$, which means significant. So that the first hypothesis "internship has an effect on entrepreneurial competence" can be accepted. Based on the questionnaire that has been answered, most of the respondents agree, with a statement stating that internship can increase the entrepreneurial competence of students. This means that the experience of industrial work practices has a positive influence on entrepreneurial competence. Collaboration between schools and industry through internship activities will produce graduate students who are ready to open businesses. Therefore the school really prepares debriefing so that the apprenticeship process is good and smooth, and has a good and positive impact on the students who carry it out.

The Effect of PUJB Subjects and Industrial Work Practices on Entrepreneurship Competence

Table 3. Test of F (Simultaneous)

\begin{tabular}{cccccc}
\hline Model & Sum of Squares & df & Mean Squares & F & Sig. \\
\hline Regression & 199.363 & 2 & 99.682 & 58.620 \\
Residual & 132.637 & 78 & 1.700 & $.000 \mathrm{a}$ \\
\hline
\end{tabular}

(Source: Data Processed By Researchers, 2020)

Based on the results of calculations on the F test, simultaneously the independent variables (PUJB and internship subjects) on the dependent variable of entrepreneurial competence) resulted in a calculated $\mathrm{F}$ value of 58.620 greater than the $t$ table of 0.949 . Meanwhile, the significant value is $0.000<0.05$, which means significant. So that in the third hypothesis "PUJB and apprenticeship subjects affect entrepreneurial competence" can be accepted. In this study it can be explained that the PUJB industry and good apprenticeship subjects will increase entrepreneurial competence.

Table 4. The results of the coefficient of determination (R2)

\begin{tabular}{cccc}
\hline $\mathrm{R}$ & $\mathrm{R}$ Square & Adjusted R Square & Std. Error of the Estimate \\
\hline 0,775 & 0,600 & 0,590 & 1,30402 \\
\hline
\end{tabular}

(Source: Data Processed By Researchers, 2020)

The coefficient of determination (Adjusted $\mathrm{R}$ square) in table 4 has a value of 0.590 . This means that the independent variables (PUJB subjects, Internship) in this study have an influence and relationship on the dependent variable (entrepreneurial competence) by $59 \%$, while the remaining $41 \%$ is influenced by other factors not listed in this study.

\section{Conclusions}

Based on the data from the results of research and tests that have been carried out, the conclusions are: (1) PUJB subjects affect the entrepreneurial competence of class XII students of the Catering Services study program at SMKN 2 Mojokerto. (2) Internship has an effect on the entrepreneurial competence of class XII students of the Catering Service study program at SMKN 2 Mojokerto. (3) PUJB and apprenticeship subjects affect the entrepreneurial competence of class XII students of the Catering Service study program at SMKN 2 Mojokerto.

\section{Acknowledgement}

The authors would like to thanks the supervisors from Magister of Vocational Educatian, State University of Surabaya for their assistance in the completed this study.

\section{Author's Contributions}

All authors discussed the results and contributed to from the start to final manuscript.

\section{Conflict of Interest}

The authors declare that they have no competing interests.

\section{References}

Agustin, M. (2017). Peran Keluarga Dalam Menumbuhkan Jiwa Wirausaha Sejak Usia Dini. Jurnal Pendidikan Volume 2 Nomor 1 Tahun 2017 Halaman: 29-32. 
Akmaliah, Z. (2009). Entrepreneurship a career choice: a analysiso of entrepreneurial self efficacy intetion on University Students.European Journal of Social Sciences. Volume 9 num. 2.

Aldrich, H. and Cliff, J. (2003).The pervasive effects of family on entrepreneurship: towards a family embeddedness perspective." Journal of Business Venturing, 18, 573-596.

Alma, B. 2000. Kewirausahaan. Bandung: ALFABETA.

Aprilia, F. (2012). Faktor-faktor yang mempengaruhi minat berwirausaha pada siswa kelas XII SMK negeri 1 kandeman kabupaten batang tahun 2011/2012. Semarang.

Badan Pemeriksa Keuangan RI. (2018). Badan Pemeriksa Keuangan Jawa Timur. https://jatim.bpk.go.id/kota-mojokerto/(diakses Selasa, 10 November 2020, pukul 22:22).

Dalyono. (2005). Psikologi Pendidikan. Jakarta: Rineka Cipta.

Deden, S. (2016). Pengaruh Ekspektasi Pendapatan, Lingkungan Keluarga, dan Pendidikan Kewirausahaan terhadap Minat Berwirausaha. Skripsi. Yogyakarta: Universitas Negeri Yogyakarta.

Dion, A. (2012). Analisis faktor-faktor motivasi yang mempengaruhi minat berwirausaha. Diponegoro Journal of Management. Vol 1, no 1.

EU. (2005). Towards a European qualifications framework for lifelong learning. Brussels: Council of the European Union.

Jacinta, M. (2018). Role of family influence, gender, and entrepreneurial education on Indonesian vocational students entrepreneurs. International Journal of Research in Bussiness and Social Science. Vol: 8 no 5: 104-112.

Jade, K. (2019). Pengaruh lingkungan keluarga dan kepribadian wirausaha terhadap niat berwirausaha. Agora. Vol 1, no 7.

Jadmiko, et al. (2018). The influence of educational support on entrepreneurial interest, family support as a moderator variable (research on economics student of bung hatta). E-journal apresiasi Ekonomi. Vol 6, no 3.

J. Mattew. (2012). Why Do Entrepreneurial Parents Have Entrepreneurial ?. Forschungsinstitutzur Zukunft der Arbeit Institute for the Study of Labor: Disscusion Paper. Amsterdam.

Jurnalmojo.com. 2018. Pertumbuhan Ekonomi Di Kota Mojokerto Stagnan, Kyai Ud: Sekitar 5,8 - 5,9 persen. http://jurnalmojo.com/ (diakses Selasa, 10 November 2020, pukul 22:24).

Kumar, S. (2015). Role of the family entrepreneurship development on Nepalisociety. The Journal of Nepalese Bussines Studies. Volume 9 no 1.

Kurniawan, A. (2016). Pengaruh lingkungan keluarga, motivasi dan kepribadian terhadap minat wirausaha. Jorunal ofEconomic Education Unnes. Vol. 5, No. 1.

Manolova. (2014). The impact of family support on young nascent entrepreneurs start-up activities: a familiy embeddedness perspective. Working Paper \# 2 (E)- 2014.Graduate Schoolof Management,St.

Petersburg State University.

Mitchelmore, S., \& Rowley, J. (2010). Entrepreneurial competencies: A literature review and development agenda. International Journal of Entrepreneurial Behavior and Research, 16(2), 92-111.

Mira, Araimi. (2015). Pengaruh lingkungan keluarga terhadap prestasi belajar siswa kelas XI SMA Negeri 3 Peusagan. JSEE-Jurnal Sains Ekonomi dan Edukasi. Vol. 3, No. 2.

Nafi'ah, S. (2018). Pengaruh kepribadian lingkungan keluarga, dan teman sebaya terhadap minat wirausaha mahasiswa program studi Pendidikan Akuntasi Fakultas Ekonomi UNY. Skripsi. Yogyakarta: UNY.

Nuryulia, A. (2014). Analisis faktor-faktor yang mempengaruhi minat wirausaha di kalanganmahasiswa. Research methods and organization studies. Halaman.134-142.

Oemar, H. (2008). Proses Belajar Mengajar. Jakarta: Bumi Aksara.

Periera, dkk. (2016). Pengaruh dukungan orang tua terhadap minat anak dalam berwirausaha. Jurnal Kesejahteraan Keluarga dan Pendidikan. Jakarta.

Ranwala, R.S. (2016). Family background, entrepreneurship specific education and entrepreneurial knowledge in venture creation. International Jurnal of Scientific and Research Publications. Volume 6, issue 9.

Scott, D. (2017). VET and entrepreneurship:research overview. Tabatha Graffin an Craig Fowler. NCVR.

Siswadi, Y. (2013). Analisis faktor internal, faktor eksternal dan pembelajaran kewirausahaan yang mempengaruhi 
minat mahasiswa dalam berwirausaha. Jurnal Manajemen dan Bisnis. Volume 13 no 01.

Slameto. (2003).Belajar dan Faktor-Faktor yang Mempengaruhinya. Jakarta: Rineka Cipta.

Subijanto. (2012). Analysis of enterpreneurship education at senior vocational school. Jurnal Pendidikan dan Kebudayaan, Vol. 18, Nomor 2, Juni 2012.

Sugiyono. (2011). Metode Penelitian Kuantitatif, Kualitatif dan RED. Bandung: Afabeta.

Sugiyono. (2013). Metode Penelitian Kuantitatif, Kualitatif dan R\&D. Bandung: Alfabeta.

Suharti, L. (2011). Faktor-faktor yang berpengaruh terhadap niat kewirausahaan. Jurnal manajemen dan kewirausahaan. Vol. 13, no. 2.

Sukardi, et al. (2019). Vocational Education: A Missing Link for the Competitive Graduates?International Education Studies. Vol. 12, no. 11.

Tittle, A et al. 2020. Entrepreneurial competences revised: developing a consolidated and categorized list of entrepreneurial competences. Entrepreneurship Education Journal (2020) 3:1-35.

Tentama, Fatwa, et al. (2019). Entrepreneuraial intention of students reviewed from self-efficacy and family support in vocational high school.International Journal of Evaluation and Research in Education. Vo. 8 No. 3.

Wiani, A, et al. (2018). Effect of family environment on interest in entrepreneurship students SMK in Subang regency. Jurnal Kajian Pendidikan Ekonomi dan Ilmu Ekonomi. Vol. 2 No 2.

Wibowo. (2011). Pembelajaran kewirausahaan dan minat wirausaha lulusan SMK. Jurnal Eksplanasi Volume 6 no 2.

Wijaya, Y. (2018). Hubungan antara lingkungan keluarga dengan minat berwirausaha pada siswa SMKN4 Surakarta. Skripsi. Solo: UNS.

Yonevy, U. (2015). Hubungan antaradukungan sosial dengan minat berwirausaha pada mahasiswa fakultas psikologi UMS. Surakarta: UMS. 